\title{
ENTREPRENEURSHIP DI PERGURUAN TINGGI \\ DAN REVOLUSI MENTAL CIVITAS ACADEMICA
}

\author{
Oleh: Kristoforus Kopong
}

\begin{abstract}
Abstrak:
ecara historis negara Indonesia termasuk negara yang paling menderita akibat krisis ekonomi pada tahun 1997 sehingga membutuhkan waktu yang lama untuk bisa bangkit lagi (recovery). Selain itu, jumlah pengangguran tingkat sarjana di Indonesia terus meningkat dari tahun ke tahun. Perguruan Tinggi belum memiliki perhatian yang serius untuk menghasilkan out put yang tidak hanya siap bekerja tetapi lebih dari itu siap untuk membuka lapangan pekerjaan. Pendidikan tinggi perlu memiliki komitmen bersama baik secara internal kelembagaan maupun secara eksternal bersama para stakeholders untuk membentuk mentalitas civitas academica dari pencari kerja menjadi pencipta lapangan pekerjaan melalui program pendidikan entrepreneurship.
\end{abstract}

Kata kunci: Entrepreneurship, Perguruan Tinggi, Revolusi Mental, Civitas Academcai.

\section{PENGANTAR}

Pada tahun 1998 perekonomian Indonesia memasuki masa yang sangat sulit. Pergantian kekuasaan dari era orde baru ke era reformasi yang disertai dengan krisis multidimensi mengakibatkan pengangguran di manamana. Perekonomian yang saat itu terpusat pada usaha-usaha besar dan konglomerasi mengalami kesulitan besar. Pengusaha besar dan konglomerat mengalami kesulitan keuangan, sehingga melakukan Pemutusan Hubungan Kerja (PHK) sepihak. Sementara itu daya beli masyarakat kian menurun. Di lain pihak, ketidakpastian sosial politik dan kebijakan publik begitu terasa hingga pada masyarakat kelas bawah. Semua orang merasa serba tidak pasti. Sistem pemerintahan berubah, acuan kebijakan dan undang-undang selalu berubah. Sikap masyarakat sangat agresif dan investor-investor asing maupun dalam negeri pergi meninggalkan Indonesia.

Di tengah-tengah ketidakpastian itu, para sarjana kesulitan mencari pekerjaan. Kondisi semacam itu juga masih dialami para serjana saat ini. Umumnya, mereka lebih memilih untuk menjadi seorang pekerja pada perusahaan-perusahaan besar maupun instansi pemerintah (menjadi PNS/ASN) guna menjamin masa depan mereka. Padahal, tak kurang dari 1703 perguruan tinggi di Indonesia setiap tahun mencetak tak kurang dari 400.000 lulusan yang akan berebut mendapatkan tempat di dunia kerja yang semakin sempit daya tampungnya akibat masih terpuruknya ekonomi negeri ini (Tias, 2009:2). Mereka menginginkan mendapat pekerjaan yang memberi income sekaligus status sosial yang terhormat. Akibatnya, lulusan perguruan tinggi hanya menambah deretan panjang pengangguran yang menjadi masalah klasik di Indonesia. Data menunjukkan bahwa 24.8\% dari jumlah pengguran di Indonesia berasal dari lulusan perguruan tinggi (Zubaedi, 2015:2). Siapakah yang harus diandalkan untuk mengatasi semuanya itu?

Tulisan ini bermaksud menunjukkan urgensi pendidikan entrepreneurship (kewirausahaan) di perguruan tinggi dalam mewujudkan revolusi mental bagi segenap civitas academica. Dengan begitu perguruan tinggi tidak hanya mencetak sarjana pencari kerja, tetapi juga sarjana yang siap membuka lapangan kerja. 


\section{Entrepreneurship sebagai Disiplin Ilmu}

Istilah entrepreneurship (kewirausahaan) berasal dari entrepreneur (bahasa Perancis) yang diterjemahkan ke dalam bahasa Inggris dengan arti between taker atau go-between dan dalam bahasa Indonesia diterjemahkan sebagai wirausaha. Kata "wirausaha" berasal dari dua kata, yaitu wira dan usaha. Wira berarti pejuang, pahlawan, manusia unggul, teladan, berbudi luhur, gagah berani, dan berwatak agung. Sedangkan usaha berarti perbuatan amal, bekerja, berbuat sesuatu. Jadi, wirausaha adalah pejuang atau pahlawan yang bekerja atau berbuat sesuatu.

Entrepreneurship kemudian diartikan secara luas sebagai “the backbone of economy”, yaitu syaraf pusat perekonomian atau sebagai "tailbone economy", yaitu pengendali perekonomian suatu bangsa (Suyaman, 2015:4). Secara epistemologi, hakikat entrepreneurship adalah suatu kemampuan dalam berpikir kreatif dan berperilaku inovatif yang dijadikan dasar, sumber daya, tenaga penggerak, tujuan, siasat, kiat dalam menghadapi tantangan hidup.

Entrepreneurship (kewirausahaan) sebagai suatu praksis hidup sebenarnya sudah ada sejak adanya manusia. Sejak itu manusia dalam keseharian hidupnya telah mempraktikan prinsip-prinsip dasar kewirausahaan, seperti optimis, ambisius, membaca peluang, sabar, siap menerima risiko, semangat, mandiri, kreatif dan inovatif serta pantang menyerah (Suryana, 2003 :7). Namun tidak semua manusia pada zaman itu menyadari dan mengembangkan prinsip-prinsip entrepreneurship tersebut secara sungguh-sungguh sebagai nadi kehidupan ekonominya.

Entrepreneurship pada zaman dahulu benar-benar sebagai praksis hidup yang dijalankan begitu saja oleh individu atau kelompok orang-orang tertentu. Keadaan ini berjalan cukup lama, sehingga terbentuklah suatu konsep bahwa jiwa entrepreneurship itu tumbuh dan berkembang karena faktor keturunan (darah/gen). Artinya, jika seseorang itu berasal dari orangtua atau keluarga yang memiliki jiwa kewirausahaan, maka dengan sendirinya orang tersebut memiliki jiwa kewirausahaan. Sebaliknya, jika seseorang bukan berasal dari orangtua atau keluarga yang memiliki jiwa kewirausahaan, maka orang tersebut juga tidak memiliki jiwa kewirausahaan. Pikiran dan pemahaman seperti itu kemudian tersosialisasi dan terindoktrinasi ke dalam alam pikiran banyak manusia zaman dahulu.

Sekarang entrepreneurship bukan hanya usaha lapangan, tetapi merupakan disiplin ilmu yang dapat dipelajari dan diajarkan. "Enterpreneurship are not only born but olso made", artinya kewirausahaan tidak hanya merupakan bakat bawaan sejak lahir atau urusan lapangan, tetapi juga dapat dipelajari dan diajarkan. Seseorang yang memiliki bakat etrepreneurship dapat mengembangkan bakatnya melalui pendidikan. Mereka yang menjadi enterpreuner adalah orang-orang yang mengenal potensi (traits) dan belajar mengembangkan potensi untuk menangkap peluang serta mengorganisir usaha dalam mewujudkan cita-citanya. Oleh karena itu, untuk menjadi wirausahawan yang sukses, memiliki bakat saja tidak cukup, tetapi juga harus memiliki pengetahuan mengenai aspek usaha yang akan ditekuninya.

Ilmu etrepreneurship adalah suatu disiplin ilmu yang mempelajari tentang nilai, kemampuan (ability) dan perilaku seseorang dalam menghadapi tantangan hidup untuk memperoleh peluang dengan berbagai risiko yang mungkin dihadapinya. Dalam konteks bisinis, menurut Thomas W. Zimmerer (1996) "Entrepreneurship is the result of a disciplined, systematic process of applying creativity and innovations to needs and opportunities in the market place". Etrepreneurship adalah hasil dari suatu disiplin, proses sistematis penerapan kreativitas dan inovasi dalam memenuhi kebutuhan dan peluang di pasar.

Dilihat dari perkembangannya, sejak awal abad ke-20, kewirausahaan sudah diperkenalkan di beberapa negara. Misalnya, di Belanda dikenal dengan "ondernemer", di Jerman dikenal dengan "unternehmer". Di beberapa negara kewirausahaan memiliki banyak tanggung jawab antara lain tanggung jawab dalam mengambil 
keputusan yang menyangkut kepemimpinan teknis, kepemimpinan organisasi dan komersial, penyediaan modal, penerimaan dan penanganan tenaga kerja, pembelian, penjualan, pemasangan iklan, dll. Kemudian pada tahun 1950-an pendidikan kewirausahaan mulai dirintis di beberapa negara seperti di Eropa, Amerika, dan Kanada. Bahkan sejak tahun 1970-an banyak universitas yang mengajarkan "enterperneurship" atau "small business management" atau "new venture management". Pada tahun 1980-an hampir 500 sekolah di Amerika Serikat memberikan pendidikan kewirausahaan. Di Indonesia Pendidikan Etrepreneurship masih terbatas pada beberapa sekolah atau perguruan tinggi tertentu saja.

\section{Interpendensi Pendidikan Entrepreneurship}

Sejalan dengan tuntutan perubahan yang cepat pada paradigma pertumbuhan yang wajar (growth-equity paradigm shift) dan perubahan ke arah globalisasi (globalization paradigm shift) yang menuntut adanya keunggulan, pemerataan, dan persaingan, maka dewasa ini sedang terjadi perubahan paradigma pendidikan (paradigm shift). Menurut Soeharto Prawirokusumo (1997:4) Pendidikan etrepreneurship (kewirausahaan) telah diajarkan sebagai suatu disiplin ilmu tersendiri yang independen (independent academic dicipline), karena:

Kewirausahaan berisi body of knowledge yang utuh dan nyata (distinctive), yaitu ada teori, konsep, dan metode ilmiah yang lengkap.

Kewirausahaan memiliki dua konsep, yaitu posisi venture start-up dan venture-growth, ini jelas tidak masuk dalam kerangka pendidikan manajemen umum (fame work general management courses) yang memisahkan antara manajemen dan kepemilikan usaha (business ownership).

Kewirausahaan merupakan disiplin ilmu yang memiliki objek tersendiri, yaitu kemampuan untuk menciptakan sesuatu yang baru dan berbeda (ability to create new and different things).

Kewirausahaan merupakan alat untuk menciptakan kemerataan berusaha dan pemerataan pendapatan (wealth creation process an enterpreuneurial endeavor by its own night, nation's prosperity, individual selfreliance) atau kesejahteraan rakyat yang adil dan makmur.

Disiplin ilmu entrepreneurship dalam perkembangannya mengalami evolusi yang sangat pesat. Pada awalnya, kewirausahaan berkembang dalam bidang perdagangan (bisnis), namun kemudian diterapkan dalam berbagai bidang lainnya, seperti: (a) Bidang agraris, meliputi pertanian dan perkebuanan serta kehutanan; (b) Bidang perikanan, meliputi pemeliharaan, penetasan, makanan dan pengangkutan ikan dan lain-lain; (c) Bidang peternakan, meliputi pemeliharaan, perkawinan, makanan, pengobatan dan lain-lain; (d) Bidang perindustrian dan kerajinan meliputi industri besar, menengah, kecil, dan pengrajin (mengolah hasil pertanian, perkebunan, perikanan, peternakan, kehutanan, dan lain-lain); (e) Bidang pertambangan dan energi; dan Bidang jasa, antara lain sebagai pedagang perantara, pemberi kredit atau perbankan, angkutan, hotel dan restoran, travel perjalanan, pengusaha asuransi, pergudangan, koperasi, dan lain-lain (Basrowi, 2011:13). Saat ini entrepreneursip juga sudah masuk dalam bidang pendidikan, kesehatan, telekomunikasi dan informasi serta institusi-institusi lain seperti lembaga pemerintahan, perguruan tinggi, dan lembaga swadaya lainnya.

\section{Objek Studi Entrepreneurship}

Objek studi entrepreneurship adalah nilai-nilai dan kemampuan (ability) seseorang yang diwujudkan dalam bentuk perilaku. Menurut Soeparman Soemahamidjaja (1997:14-15), kemampuan seseorang yang menjadi objek entrepreneurship meliputi:

Kemampuan merumuskan tujuan hidup/usaha. Dalam merumuskan tujuan hidup/usaha tersebut perlu permenungan, koreksi, yang kemudian berulang-ulang dibaca dan diamati sampai memahami apa yang menjadi kemauannya. 
Kemampuan memotivasi diri untuk melahirkan suatu tekad kemauan yang menyala-nyala.

Kemampuan untuk berinisiatif, yaitu mengerjakan sesuatu yang baik tanpa menunggu perintah orang lain, yang dilakukan berulang-ulang sehingga menjadi kebiasaan berinisiatif.

Kemampuan berinovasi yang melahirkan kreativitas (daya cipta) setelah dibiasakan berulang-ulang akan melahirkan motivasi. Kebiasaan inovatif adalah desakan dalam diri untuk selalu mencari berbagai kemungkinan baru atau kombinasi baru apa saja yang dijadikan peranti dalam menyajikan barang dan jasa bagi kemakmuran masyarakat.

Kemampuan untuk membentuk modal uang atau barang modal (capital goods).

Kemampuan untuk mengatur waktu dan membiasakan diri untuk selalu tepat waktu dalam segala tindakan melalui kebiasaan yang selalu tidak menunda pekerjaan.

Kemampuan mental yang dilandasi dengan agama.

Kemampuan untuk membiasakan diri dalam mengambil hikmah dari pengalaman yang baik maupun menyakitkan.

Dalam bidang-bidang tertetu objek entrepreneurship telah menjadi kompetensi inti (core competency) yaitu kreatif dan inovatif. Melalui proses kreatif dan inovatif, seorang entrepreneur dapat menciptakan nilai tambah atas barang dan jasa. Nilai tambah barang dan jasa yang diciptakan melalui proses kreatif dan inovatif banyak menciptakan berbagai keunggulan termasuk keunggulan bersaing.

\section{ENTREPRENEURSHIP DI PERGURUAN TINGGI}

\section{Dasar Hukum Pendidikan Enterpreneurship}

Dasar kebijakan pendidikan entrepreneurship adalah Pancasila dan Undang-Undang Dasar Republik Indonesia Tahun 1945. Pancasila dan Undang-Undang Dasar Negara Republik Indonesia Tahun 1945 memberikan landasan filosofis serta berbagai prinsip dasar dalam pembangunan pendidikan. Berdasarkan landasan filosofis tersebut, sistem pendidikan nasional menempatkan peserta didik sebagai makhluk yang diciptakan oleh Tuhan Yang Maha Esa dengan segala keberadaannya dengan tugas memimpin kehidupan yang berharkat dan bermartabat dan menjadi manusia yang bermoral, berbudi luhur, mandiri, kreatif, inovatif dan berakhlak mulia.

Lebih lanjut dalam Undang-Undang No. 20 Tahun 2003 tentang Sistem Pendidikan Nasional, Pasal 3 ditegaskan bahwa: "Pendidikan nasional berfungsi mengembangkan kemampuan dan membentuk watak serta peradaban bangsa yang bermartabat dalam rangka mencerdaskan kehidupan bangsa, bertujuan untuk berkembangnya potensi peserta didik agar menjadi manusia yang beriman dan bertakwa kepada Tuhan Yang Maha Esa, berakhlak mulia, sehat, berilmu, cakap, kreatif, mandiri, dan menjadi warga negara yang demokratis serta bertanggung jawab”.

Secara operasional perintah undang-undang di atas dikonkritkan dalam Instruksi Presiden No. 4 Tahun 1995 tentang Gerakan Nasional Memasyakatkan dan Membudayakan Kewirausahaan. Inpres ini memberikan arah dalam melaksanakan gerakan memasyarakatkan dan membudayakan kewirausahaan (entrepreneurship) di sektor masing-masing sesuai dengan tugas, kewenangan dan tanggung jawabnya di bawah koordinasi Menteri Koperasi dan Pembinaan Pengusaha Kecil. Melalui gerakan ini diharapkan budaya kewirausahaan akan menjadi bagian dari etos kerja masyarakat dan bangsa sehingga dapat melahirkan wirausahawan-wirausahawan baru yang handal, tangguh dan mandiri.Konkretisasi lebih lanjut dibuatlah Surat Keputusan Bersama Menteri Negara Koperasi dan UKM dan Menteri Pendidikan Nasional No. 02/SKB/MENEG/VI/2000 dan No. 4/U/SKB/2000 tertanggal 29 Juni 2000 tentang Pendidikan Perkoperasian dan Kewirausahaan. Tujuan dari SKB adalah 
memasyarakatkan dan mengembangkan perkoperasian dan kewirausahaan melalui pendidikan, serta menyiapkan kader-kader koperasi dan wirausahawan melalui berbagai program pelatihan.

Akhirnya, tahun 2008 pemerintah melalui Departemen Koperasi dan UKM telah mencanangkan Program GETUKNAS (Gerakan Tunas Kewirausahaan Nasional) untuk pelajar SMA dan mahasiswa. Kemudian gerakan ini disusul oleh gerakan nyata dari Dirjen Dikti pada tahun 2009 yang mewajibkan bagi perguruan tinggi memasukkan mata kuliah kewirausahaan ke dalam kurikulum sebagai mata kuliah wajib dalam 2 semester. Sebagai bukti semangat gerakan kewirausahaan dan langkah mewujudkan instruksi dari Dirjen Dikti, maka pendidikan kewirausahaan umumnya diberikan dalam bentuk mata kuliah kewirausahaan dengan bobot 2-4 sks.

\section{Program Enterpreneurship di Perguruan Tinggi}

Beberapa program kewirausahaan (entrepreneurship) yang dapat dilakukan di perguruan tinggi dalam mempersiapkan para lulusannya sebagai calon wirausaha baru sebagai berikut (bdk. Ditjen Dikti, 2010a dan 2010b):

\section{Program Mahasiswa Wirausaha (PMW)}

Program Mahasiswa Wirausaha (PMW) merupakan bagian dari sistem pendidikan di perguruan tinggi yang telah diluncurkan semenjak tahun 2009. Dalam pelaksanaannya, PMW terintegrasi dengan pendidikan kewirausahaan yang sudah ada, antara lain dengan: Program Kreativitas Mahasiswa (PKM), Kuliah Kerja Usaha (KKU) dan program kewirausahaan lain.

Tujuan Program MW adalah: (1) menumbuhkan motivasi berwirausaha di kalangan mahasiswa; (2) membangun sikap mental wirausaha, yakni: percaya diri, sadar akan jati dirinya, bermotivasi untuk meraih suatu citacita, pantang menyerah, mampu bekerja keras, kreatif, inovatif, berani mengambil risiko dengan perhitungan, berperilaku pemimpin dan memiliki visi ke depan, tanggap terhadap saran dan kritik, memiliki kemampuan empati dan keterampilan sosial; (3) meningkatkan kecakapan dan keterampilan para mahasiswa khususnya sense of business; (4) menumbuhkembangkan wirausaha-wirausaha baru yang berpendidikan tinggi, (5) menciptakan unit bisnis baru yang berbasis ilmu pengetahuan, teknologi dan seni; dan (6) membangun jejaring bisnis antarpelaku bisnis, khususnya antara wirausaha pemula dan pengusaha yang sudah mapan.

\section{Program Kuliah Kewirausahaan (KWU)}

Dalam usaha mewujudkan calon-calon pengusaha muda terdidik atau pengusaha muda pemula dan menumbuhkembangkan budaya kewirausahaan di perguruan tinggi dapat dimulai dengan program KWU. Penyelenggaraan KWU dimaksudkan sebagai upaya memperkenalkan dunia kewirausahaan agar dapat menumbuhkembangkan jiwa kewirausahaan bagi kalangan mahasiswa.

Tujuan Program KWU adalah: (1) meningkatkan pemahaman dan penjiwaan kewirausahaan di kalangan mahasiswa agar mampu menjadi wirausahawan yang berwawasan jauh ke depan dan luas berbasis ilmu yang diperolehnya; (2) mengenal pola berpikir wirausaha serta meningkatkan pemahaman manajemen (organisasi, produksi, keuangan dan pemasaran); dan (3) memperkenalkan cara melakukan akses informasi dan pasar serta teknologi, cara pembentukan kemitraan usaha, strategi dan etika bisnis, serta pembuatan rencana bisnis atau studi kelayakan yang diperlukan mahasiswa agar lebih siap dalam pengelolaan usaha yang sedang akan dilaksanakan.

Program Magang Kewirausahaan (MKU) 
Program magang kewirausahaan merupakan kegiatan mahasiswa untuk belajar bekerja secara nyata (praktik) pada usaha kecil menengah, yang diharapkan dapat menjadi wahana penumbuhan jiwa kewirausahaan. Magang merupakan salah satu cara mempersiapkan diri untuk menjadi wirausaha. Selama magang mahasiswa bekerja sebagai tenaga kerja di perusahaan mitra, sehingga mampu menyerap berbagai pengalaman praktik.

Tujuan Program MKU adalah: (1) meningkatkan kemampuan untuk menerapkan pengetahuan dan keterampilan yang dimiliki; (2) meningkatkan pengetahuan kewirausahaan mahasiswa, baik dalam hal keilmuan maupun pengalaman berwirausaha; (3) meningkatkan kemampuan berkomunikasi dan bersosialisasi dengan kalangan masyarakat di perusahaan; (4) memacu motivasi kewirausahaan mahasiswa yang berminat menjadi calon wirausaha; (5) membuka peluang untuk memperoleh pengalaman praktis kewirausahaan bagi dosen pembimbing mahasiswa; dan (6) menciptakan keterkaitan dan kesepadanan antara perguruan tinggi dengan usaha kecil dan menengah.

\section{Program Kuliah Kerja Usaha (KKU)}

Untuk menjadi wirausahawan, mahasiswa perlu dibekali kemampuan praktis yang mencakup keterampilan menerapkan iptek, keterampilan manajerial wirausaha dan pemasaran serta adopsi inovasi teknologi. Pengalaman ini dapat diperoleh mahasiswa melalui Kuliah Kerja Usaha (KKU), di mana kemampuan praktis ditumbuhkembangkan dengan berperan aktif, antara lain membantu usaha rumah tangga atau usaha kecil menengah tempat mahasiswa bermitra.

Tujuan Program KKU, yaitu: (1) berkembangnya budaya kewirausahaan di perguruan tinggi; (2) terwujudnya calon sarjana yang cendekiawan dan berjiwa kewirausahaan serta sadar dengan masalah lingkungannya; dan (3) menumbuhkembangkan usaha kecil menengah yang memiliki daya saing tinggi dari segi kualitas produk/jasa, kinerja dan pemasaran.

Inkubator Wirausaha Baru (INWUB)

Inkubator Wirausaha Baru (INWUB) adalah suatu fasilitas fisik yang dikelola oleh sejumlah staf dan menawarkan suatu paket terpadu kepada alumni perguruan tinggi yang berminat menjadi wirausahawan dengan biaya terjangkau selama jangka waktu tertentu (2-3 tahun).

Tujuan dibentuknya INWUB, yaitu untuk: (1) menciptakan lapangan kerja baru sehingga meningkatkan standar hidup golongan ekonomi lemah; (2) menciptakan UKM yang mandiri dan berlandaskan iptek untuk memperkuat struktur ekonomi nasional; (3) membantu alih teknologi dari teknologi konvensional ke teknologi mutakhir (state of the art technology) yang tepat guna termasuk teknologi hasil putaran (spin off) industri besar, perguruan tinggi atau lembaga penelitian; dan (4) mempercepat perkembangan kewirausahaan di Indonesia untuk mencapai pengembangan ketahanan ekonomi yang berkelanjutan dalam menghadapi era perdagangan bebas.

Berbagai program tersebut di atas, merupakan bentuk nyata perhatian pemerintah dalam mewujudkan lulusan perguruan tinggi yang memiliki kompetensi kewirausahaan sesuai dengan kebutuhan masyarakat dan tuntutan dunia kerja. Kompetensi kewirausahaan dimaksud tidak hanya memiliki ilmu pengetahuan (tataran teori), tetapi juga keterampilan, dan kualitas individu yang meliputi sikap, motivasi, nilai serta tingkah laku yang diperlukan untuk melaksanakan pekerjaan/kegiatan usaha (Suryana, 2003:65). Keterampilan-keterampilan yang harus dimiliki di antaranya keterampilan manajerial (managerial skill), keterampilan konseptual (conceptual skill), dan keterampilan mengerti, berkomunikasi, dan berelasi (human skill) dan keterampilan merumuskan masalah dan mengambil keputusan (decision making skill), keterampilan mengatur dan menggunakan waktu (time management skill), dan keterampilan teknik lainnya secara spesifik (bdk. Basrowi, 
2011: 32-33). Akan tetapi memiliki pengetahuan dan keterampilan saja tidaklah cukup. Wirausaha harus memiliki sikap positif, motivasi, dan selalu berkomitmen terhadap pekerjaan yang sedang dilakukannya.

\section{Unsur-unsur Entrepreneurship di Perguruan Tinggi}

Pelaksanaan pendidikan entrepreneurship di perguruan tinggi beserta program-programnya dapat dilaksanakan secara efektif apabila mendapat dukungan dari beberapa unsur penting berikut (bdk. Ditjen Dikti, 2010a dan 2010b):

\section{Unsur Mahasiswa}

Mahasiswa merupakan individu yang sangat potensial dalam upaya menanamkan jiwa kewirausahaan. Banyak potensi dan peluang dapat dimanfaatkan mahasiswa untuk kepentingan pembelajaran dan pembumian sistem budaya kewirausahaan di perguruan tinggi. Mahasiswa perlu merespon positif pendidikan kewirausahaan dan berbagai programnya. Pendidikan kewirausahaan bukan hanya sebatas menu tambahan dalam perkuliahan, tetapi suatu persiapan diri yang sistematis dan terpadu menuju dunia kerja di era globalisasi dan pasar bebas.

\section{Unsur Kurikulum}

Kurikulum didesain sedemikian rupa untuk dijadikan acuan dalam penyelenggaraan perkuliahan mahasiswa. Kenyataannya tidak semua jurusan/program studi menyajikan mata kuliah kewirausahaan secara otonom. Untuk itu, kebijakan pencantuman mata kuliah kewirausahaan ini dalam kurikulum jurusan yang ada di perguruan tinggi harus dikaji secara baik. Pencatuman mata kuliah kewirausahaan tidak perlu mempermasalahkan koherensi substansi mata kuliah kewirausahaan dengan bidang ilmu utama pada jurusan di perguruan tinggi. Hal ini menjadi penting ketika daya serap lulusan perguruan tinggi terhadap kompetensi yang diampu relatif kecil, dan ke depan diprediksi akan semakin kecil.

\section{Unsur Dosen}

Dosen pengampuh mata kuliah kewirausahaan menempati peran strategis menumbuhkan jiwa kewirausahaan pada mahasiswa. Karena itu dosen kewirausahaan harus memiliki kompetensi di ranah pengetahuan (teori) dan ranah keterampilan (praktek) kewirausahaan. Sekurang-kurangnya dosen harus memiliki dan mengembangkan jiwa kewirausahaan. Pengembangan jiwa kewirausahaan dosen dapat dilakukan melalui hal-hal sebagai berikut: (a) Kewirausahaan dosen dibangun di atas disiplin keilmuannya; (b) Dosen memerlukan penguatan dalam bentuk pendidikan, pelatihan, dan pemagangan; dan (d) Dukungan lingkungan seperti Dunia Usaha-Dunia Industri (DUDI).

Unsur Metode Pembelajaran Kewirausahaan

Pendekatan pembelajaran yang berpusat pada guru/dosen (teacher-centered learning/TCL) kurang efektif dalam mendorong mahasiswa untuk memenuhi kompetensi soft skil-lnya. Pendekatan pembelajaran kewirausahaan yang sesuai harus berpusat pada mahasiswa (student-centred learning/SCL) dengan berbagai metode, seperti: (a) Berbagi informasi (information sharing); (b) Belajar dari pengalaman (experience based) dan (c) Pemecahan masalah (problem solving based). Anjuran ini sangat tepat karena pendekatan SCL mampu menempatkan mahasiswa pada posisi yang berperan aktif dalam mendapat pengetahuan, keterampilan, dan pengalaman yang dibutuhkannya sesuai dengan nilai-nilai kewirausahaan yang harus dimilikinya.

Unsur Atmosfer Kewirausahaan

Atmosfer kewirausahaan (academic entrepreneurship) secara kongkrit merupakan suasana kewirausahaan yang sengaja diciptakan oleh perguruan tinggi agar mendukung penyelenggaraan pendidikan kewirausahaan sebagaimana mestinya. Tentunya hal ini sejalan dengan upaya menjadikan perguruan tinggi sebagai entrepreneurial university/campus atau entrepreneurship-based university/campus 
Strategi untuk mewujudkan perguruan tinggi sebagai entrepreneurial university/campus, yaitu:

Penyusunan kurikulum melibatkan pelaku usaha dan motivator agar menghasilkan konsep dan gagasan kewirausahaan yang tepat dan sesuai dengan mahasiswa dari berbagai disiplin ilmu.

Membentuk pusat kewirausahaan (entrepreneurship centre) sebagai unit usaha yang menaungi dan mengelola berbagai kegiatan kewirausahaan mahasiswa dan dosen.

Membangun kerjasama dengan dunia usaha untuk (1) meningkatkan kualitas SDM dosen dan mahasiswa, (2) membuka peluang magang usaha bagi mahasiswa dan dosen, (3) membuka peluang kerjasama usaha khususnya untuk mahasiswa/alumni.

Membangun kerjasama dengan institusi keuangan (perbankan/non perbankan) agar mahasiswa yang akan membuka usaha dapat diberikan kemudahan dalam mengakses modal usaha.

Menerapkan entrepreneurship award sehingga mendorong dan meningkatkan semangat berwirausaha, sekaligus mendidik semangat berkompetisi secara fair di kalangan mahasiswa.

\section{Enterpreneurship dan Revolusi Mental Civitas Academica}

Suatu fakta yang tak terbantahkan bahwa setiap tahun juta-an sarjana dari berbagai lembaga perguruan tinggi sibuk mencari pekerjaan. Pekerjaan yang menjadi sasaran utama pencarian para sarjana adalah Pegawai Negeri Sipil (PNS). Hal ini karena memang di kalangan masyarakat pada umumnya Pegawai Negeri Sipil (PNS) dipandang selain menjamin kepastian pendapatan dan ekonomi tetapi dirasakan sebagai peningkatan status sosial. Karena itu, kebanyakan orang tua mengharapkan agar anaknya kelak bekerja sebagai PNS. Namun kenyataan lain saat ini menunjukkan secara jelas bahwa akibat ketersediaan lapangan pekerjaan yang tidak sebanding dengan jumlah pencari lapangan kerja, maka tidak sedikit dari para sarjana yang memperpanjang barisan para penganggur. Hal ini tentu menjadi beban berat bagi keluarga, masyarakat, bangsa dan negara.

Untuk keluar dari persoalan pengangguran dan beban ekonomi tersebut di atas, perlu upaya yang sistematis dan berkelanjutan. Sebab pengangguran bukan hanya sekedar persoalan krisis ekonomi dan ketidak tersediaan lapangan pekerjaan tetapi lebih pada persoalan mentalitas manusia. Karena itu, perlu upaya yang serius untuk melakukan revolusi mental seturut semangat Presiden Soekarno (1956) bahwa revolusi mental merupakan upaya menggembleng manusia Indonesia agar menjadi manusia baru yang berhati putih, berkemauan baja, bersemangat elang rajawali, berjiwa api yang menyala-nyala (Ditjen Informasi dan Komunikasi Publik, 2015:3). Kini revolusi mental itu digemakan kembali oleh Presiden Joko Widodo (2016) dalam Inpres No. 12 Tahun 2016 tentang Gerakan Nasional Revolusi Mental. Tiga pokok nilai esensial dari gerakan tersebut, yaitu integritas (jujur, dipercaya, berkarakter, dan tanggung jawab), kerja keras (etos kerja, daya saing, optimis, inovatif, dan produktif) dan gotong royong (kerja sama, solidaritas, komunal, dan berorientasi pada kemaslahatan).

Salah satu upaya yang amat strategis dalam menginternalisasikan nilai-nilai esensial revolusi mental, yakni melalui pendidikan entrepreneurship. Menurut Wasty Soemanto (2006:87), pendidikan entrepreneurship adalah pertolongan untuk membelajarkan manusia Indonesia sehingga mereka memiliki kekuatan pribadi yang dinamis, inovatif dan kreatif untuk menjalankan usahanya sesuai dengan kepribadian bangsa Indonesia yang berdasarkan Pancasila. Letak urgensi pendidikan entrepreneurship adalah menciptakan manusia yang kreatif dan inovatif sehingga berguna bagi diri sendiri, masyarakat, dan bangsa.

Sri H. Wahyuningsih dan Ika Nurul Qamari (2011:4-5) mengemukakan beberapa alasan pentingnya pendidikan entrepreneurship, sebagai berikut: (1) Merupakan soft skills yang harus diberikan; (2) Memberikan bekal kemandirian, tangguh, keuletan; (3) Dituntut menciptakan pekerjaan melalui wirausaha; (4) Bekal ulet bermasyarakat; (5) Tidak tergantung pada sektor formal untuk mengurangi pengangguran; (6) Pendidikan 
entrepreneurship merupakan life skills agar dapat bersaing di dunia global; (7) Memberikan alternatif karir setelah lulus dan mengembangkan potensi mengatasi pengangguran (self employed); (8) Dapat digunakan dalam berbagai bidang kehidupan, baik profit maupun non profit; (9) Para lulusan tidak harus bekerja di sektor formal, tapi dapat menciptakan pekerjaan dan menjadi manajer sehingga mengurangi pengangguran; dan (10) Merubah mental lulusan dari mental menjadi pegawai ke mental berwirausaha yang memiliki daya saing dan daya juang yang tinggi.

Dalam konteks perguruan tinggi dengan berbagai program dan strategi pendidikan enterpreneurship diharapkan mampu menggeser mentalitas dan orientasi para lulusan agar lebih mengarah pada penciptaan lapangan pekerjaan. Hal ini mesti menjadi komitmen bersama seluruh anggota perguruan tinggi, seperti mahasiswa, staf dosen, tenaga kependidikan, karyawan, manajemen, bahkan pihak yayasan terhadap semangat, dorongan, dukungan dalam mewujudkan perguruan tinggi sebagai pusat kewirausahaan. Selain itu perlu adanya hubungan timbal balik yang harmonis antara perguruan tinggi dengan berbagai stakeholders yang ada di sekitar lingkungan perguruan tinggi, seperti organisasi bisnis, industri, pemerintah, dan komunitas masyarakat termasuk alumni. Inilah bentuk social support dan dukungan lingkungan usaha yang merupakan faktor kontekstual yang berpengaruh positif terhadap niat kewirausahaan.

Out put dari proses pendidikan entrepreneurship di perguruan tinggi adalah membentuk civitas academica dan para sarjana sebagai agent of change yang memiliki tiga kekuatan $(3 \mathrm{H})$, yaitu: $\mathrm{H}$ pertama head atau kepala yang diartikan sebagai pemikiran, dan dalam pembelajaran diisi oleh pengetahuan tentang nilainilai, semangat, dan jiwa kewirausahaan, agar civitas academica dan para sarjana memiliki pemikiran kewirausahaan. H kedua, heart atau hati yang diartikan sebagai perasaan, diisi oleh penanaman empatisme sosial-ekonomi, agar civitas academica dan para sarjana dapat merasakan suka-duka berwirausaha dan memperoleh pengalaman empiris dari para wirausaha terdahulu. Selanjutnya H ketiga, hand atau tangan yang diartikan sebagai sikap, perilaku, dan keterampilan yang harus dimiliki oleh civitas academica dan para sarjana untuk berwirausaha. Dengan demikian pendidikan entrepreneurship mampu mengubah mind-set civitas academica dan para lulusan perguruan tinggi dari mencari pekerjaan (job seeker) menjadi pencipta lapangan kerja (job creator). Hal ini tentu dapat mendorong akselerasi pemulihan ekonomi (economy recovery) di Indonesia.

Sejalan dengan semangat tersebut sejak tahun 2015 negara-negara di kawasan Asia Tenggara berkomitmen mewujudkan Masyarakat Ekonomi Asean (MEA). Lima elemen MEA, yaitu investasi, barang, jasa, modal, dan tenaga kerja terampil. Kekuatan utama dalam mewujudkan MEA adalah sumber daya manusia yang kreatif, inovatif, solutif dan dapat memanfaatkan sumber daya alam yang ada (Deputi Bidang Koordinasi Pendidikan dan Agama, 2016:3). Oleh karena itu, segenap civitas academica harus melihat pendidikan entrepreneurship sebagai peluang untuk menimbah pengetahuan melalui penyajian teori di ruang kuliah dan sekaligus pengalaman melalui berbagai program dan praktik entrepreneurship yang dikembangkan di perguruan tinggi.

\section{RELEVANSI ENTREPRENEURSHIP DI STIPAR}

Bagaimana dengan Stipar (Sekolah Tinggi Pastoral Atma Reksa) sebagai lembaga pendidikan tinggi yang secara khusus mendidikan para calon guru agama (katekis). Sejak tahun 2016, Stipar menganti mata kuliah Koperasi dengan mata kuliah Kewirausahaan (entrepreneurship). Perubahan itu berdasarkan hasil pertemuan penyusunan kurikulum berbasis KKNI di Detusoko pada tanggal 5-7 Agustus 2016 yang dihadiri oleh para dosen dan tenaga kependidikan. Pada Tahun Akademik 2016/2017 Kewirausahaan (entrepreneurship) kemudian dijadikan sebagai salah satu mata kuliah yang diajakan pada Semester I dengan 2 SKS. Berdasarkan 
pengalaman tersebut, ternyata 2 SKS itu dirasakan tidak cukup untuk mengembangkan minat dan menumbuhkan jiwa entrepreneurship di kalangan civitas academica secara khusus mahasiswa. Proses pembelajaran mahasiswa masih sebatas penyajian teori, sedangkan praktek belum dapat dilaksanakan secara terencana karena keterbatasan waktu. Oleh karena itu, pada Tahun Akademik 2017/2018 untuk mata kuliah Kewirausahaan (Entrepreneurship) ditambah 2 SKS sehingga menjadi 4 SKS (2 SKS teori dan 2 SKS lainnya untuk praktek).

Relevansi mata kuliah Kewirausahaan (entrepreneurship) dengan jurusan Kateketik Pastoral secara khusus Program Studi Keagamaan Katolik sebenarnya terletak pada menciptakan daya saing agar mampu berkompetisi dalam dunia kerja nanti. Visi program studi Kateketik Pastoral adalah terbentuknya tenaga pendidik dan rasul awal yang beriman teguh, pancasilais, profesional, inovatif dan menghayati etos kerja (Stipar, 2017:14). Pembentukan dan pengembangan jiwa entrepreneurship mahasiswa Stipar dalam bentuk pendidikan kewirausahaan berdampak dalam penciptaan daya saing mereka ketika harus kompetisi, baik pada tingkat daerah, nasional maupun internasional. Komitmen ini senantiasa disegarkan sebagai bentuk tanggung jawab untuk menjadikan Stipar sebagai perguruan tinggi terdepan dan memberikan pelayanan yang memuaskan bagi pembangunan khususnya spiritual-keagamaan. Hal ini sesuai dengan visi Stipar, yaitu "Terwujudnya Stipar sebagai Lembaga Pendidikan Tinggi yang unggul dalam penyelenggaraan Tridarma Perguruan Tinggi demi menghasilkan Tenaga Pendidik Agama Katolik dan Rasul Awam yang berkualitas" (Stipar, 2017:13). Searah dengan itu perlu dilakukan evaluasi untuk terus memperbaharui program-programnya agar relevan dengan tuntutan pasar/penggunanya (user).

Pada satu sisi Stipar dituntut untuk menawarkan kompetensi akademik kepada mahasiswa agar mampu menguasai konsep, prinsip, teori, metodologi, dan aplikasi dalam praktik sebagai ahli-ahli (profesional) dalam bidang pekerjaan teknis/praktis dan idealis Kateketik Pastoral dan Keagamaan Katolik. Melalui berbagai program studi, Stipar akan mempersiapkan lulusan sebagai sarjana pendidikan S.Pd secara khusus pendidikan agama Katolik yang memiliki pengetahuan/wawasan, ketrampilan dan sikap agamawan yang bisa menangani dan memecahkan berbagai tugas di masyarakat/umat. Namun pada sisi lain mahasiswa Stipar perlu dibekali pula dengan ketrampilan entrepreneur atau berwirausaha ketika peluang kerja pada sektor yang sesuai disiplin ilmu tidak tersedia. Dengan demikian, sasaran yang akan dicapai melalui penyelenggaraan pendidikan entrepreneurship akan memungkinkan lulusan Stipar memiliki kompetensi mayor dalam ilmu agama, dengan menjadi tenaga ahli Kateketik Pastoral dan Pendidikan Keagamaan Katolik yang mampu melaksanakan tugas dan pengabdian dalam bidang pembangunan agama. Selain itu, ia memiliki kompetensi minor yang sifatnya skill dalam kewirausahaan. Atas pertimbangan ini, maka para lulusan akan memiliki kompetisi yang lengkap, yaitu (1) kompetensi utama: ahli Kateketik Pastoral dan Pendidikan Keagamaan Katolik serta rasul awam; (2) kompetensi pendukung mampu menganalisis dan memecahkan masalah-masalah sosial keagamaan; (3) kompetensi lain-lain memahami praktik pemecahan permasalahan mutu, daya saing, otonomi pengelolaan, dan kesehatan organisasi pendidikan; (4) kompetensi dalam bidang kewirausahaan (bdk, Stipar, 2017:15).

Jika upaya di atas dilakukan maka para alumni Stipar tidak akan kekurangan lahan untuk mengabdi. Dalam kultur masyarakat NTT yang agamis (mayoritas Katolik), alumni bisa mendedikasikan ilmunya pada bidang Kateketik Pastoral dan Pendidikan Keagamaan Katolik. Secara empirik, mereka bisa mengambil peranperan konvensional selama ini seperti sebagai katekis (ahli kateketik), guru (pendidik agama Katolik), dan penyuluh (agama Katolik). Di luar itu, mereka juga bisa berperan sebagai entrepreneur (pelaku kewirausahaan). Entrepreneur akan mampu melihat semua peluang kemudian memanfaatkan dan mewujudkan peluang tersebut untuk menciptakan sesuatu yang baru dan berbeda (create new and different) yang dapat menciptakan nilai 
(Saiman, 2009:42). Inilah makna revolusi mental sebagai gerakan untuk mengubah cara pandang, pikiran, sikap, perilaku, dan cara kerja untuk dapat berorientasi pada kemajuan dan kemodernan.

Sejauh ini kiprah alumni Stipar kebanyakan lebih terfokus pada sektor tenaga pendidik (guru agama), birokrasi (PNS) pada Kementerian Agama, penyuluh agama, dan katekis (fungsionaris pastoral), sebagian kecil terjun sebagai teoritisi dan praktisi dalam perpolitikan daerah (lokal) serta aktivis di sebuah NGO. Sementara yang kiprahnya sebagai entrepreneur mungkin lebih sedikit lagi. Namun untuk lebih jelas memang perlu dilakukan pengecekan melalui penelitian secara mendalam.

\section{PENUTUP}

Pendidikan entrepreneurship di perguruan tinggi merupakan upaya menginternalisasikan jiwa dan mental kewirausahaan melalui institusi pendidikan. Hal ini relevan sebab melalui pendidikan entrepreneurship tersebut dapat mengubah sikap dan mental civitas academica menjadi entrepreneur yang percaya diri, disiplin, kreatif dan inovatif serta yang paling utama adalah menyukai tantangan serta mau mengambil resiko. Sikap dan mental entrepreneurship ini sangat tepat untuk merespon pasar bebas di era globalisasi saat ini. Oleh karena itu pendidikan entrepreneurship dapat dilaksanakan di perguruan tinggi dan diberlakukan kepada semua mahasiswa tanpa memandang bidang ilmu yang dipelajari, karena pendidikan kewirausahaan bukan pendidikan bisnis.

Bagi civitas academica Stipar, Pendidikan entrepreneurship dinilai sebagai sebuah tawaran positif yang juga sudah mulai direspon secara positif pula. Respon positif itu didasarakan atas pertimbangan yang matang untuk membekali para civitas academica, khususnya mahasiswa agar kelak bisa bersaing di dunia kerja. Saat ini masyarakat pada umumnya menginginkan para sarjana termasuk lulusan Stipar dapat merealisasikan harapan yang tidak hanya bersifat akademik (academic expectations) tetapi juga bersifat sosial (social expectations) dan pragmatis/praktis dan bermanfaat (pragmatic expectation).

Pengetahuan dan pengalaman entrepreneurship pada masa kuliah dapat menumbuhkan kompetensi inti (core competency) dalam menciptakan perubahan, pembaharuan, dan kemajuan. Kompetensi itu tidak hanya digunakan sebagai kiat-kiat entrepreneurship dan binis jangka pendek tetapi juga sebagai kiat yang membingkai kehidupan para lulusan perguruan tinggi (never ending process). Dengan demikian mereka dapat menciptakan lapangan pekerjaan baik bagi diri sendiri, keluarga, dan orang lain. Petuah bijak mengingatkan: "Jika kepala (head) atau otakmu pintar sebaikanya engkau menjadi profesor; jika hati (heart) atau batinmu suci sebaiknya engkau menjadi rahib; dan jika tangan (hand) atau fisikmu kuat sebaiknya engkau menjadi prajurit; tetapi jika otakmu pintar, hatimu suci dan fisikmu kuat sebaiknya engkau menjadi wirausahawan (entrepreneur)".

\section{Kepustakaan}

Basrowi. 2011. Kewirausahaan untuk Perguruan Tinggi. Ghalia Indonesia: Bogor.

Deputi Bidang Koordinasi Pendidikan dan Agama. 2016. Pembangunan Pendidikan Tinggi dan Revolusi Mental. Materi Sosialisasi disampaikan oleh Asril Asisten Deputi Pendidikan Tinggi dan Pemanfaatan Iptek. Kementerian Koordinator Bidang Pembangunan Manusia dan Kebudayaan, Yogyakarta, 4 Desember. 
Ditjen Dikti, Badan Penelitian dan Pengembangan. 2010a Laporan Hasil Penelitian Alternatif Pelaksanaan Pendidikan Kewirausahaan di Perguruan Tinggi. bekerjasama dengan Universitas Negeri Jakarta, Kemdiknas, Jakarta.

Ditjen Dikti, Badan Penelitian dan Pengembangan. 2010b. Pedoman Umum Pengembangan Model Inkubator Bisnis Perguruan Tinggi. Balitbang Kemdiknas bekerja sama dengan Universitas Brawijaya, Malang.

Ditjen Informasi dan Komunikasi Publik Kementerian Komunikasi dan Informatika RI, Government Public Relations Riport: Revolusi Mental. Edisi 5 Juli 2015.

Instruksi Presiden No. 4 Tahun 1995 tentang Gerakan Nasional Memasyakatkan dan Membudayakan Kewirausahaan.

Instruksi Presiden No. 12 Tahun 2016 tentang Gerakan Nasional Revolusi Mental

Prawirokusumo, Soeharto. 1997. Peran Perguruan Tinggi dalam Menciptakan Wirausaha-Wirausaha Tangguh. Makalah Seminar. Jatinangor: PIBI.INKOPIN.

Saiman, Leonardus. 2009. Kewirausahaan: Teori, Praktik, dan Kasus-Kasus. Salemba Empat: Jakarta.

Soemahamidjaja. 1997. Wiraswasta Orientasi Konsepsi dan Ikrar. Tugas Wiraswasta: Bandung.

Soemanto, Wasty. 2006. Pendidikan Kewirausahaan. Binaaksara: Bandung.

Stipar. 2017. Pedoman Akademik Sekolah Tinggi Pastoral Atma Reksa, Ende.

Surat Keputusan Bersama Menteri Negara Koperasi dan UKM dan Menteri Pendidikan Nasional No. 02/SKB/MENEG/VI/2000 dan No. 4/U/SKB/2000 tertanggal 29 Juni 2000 tentang Pendidikan Perkoperasian dan Kewirausahaan.

Suryana. 2003. Kewirausahaan, Pedoman Praktis: Kiat dan Proses Menuju Sukses. Jakarta: Salemba Empat.

Suyaman, Dede Jajang. 2015. Kewirausahan dan Industri Kreatif. Alfabeta: Bandung.

Tias, Diyah Retno Ning. 2009. "Hubungan Antara Motivasi Berprestasi dengan Entrepreneurship pada Mahasiswa UMS”, Skripsi, Fakultas Psikologi UMS.

Undang-Undang No. 20 Tahun 2003 tentang Sistem Pendidikan Nasional

Wahyuningsih, Sri Handari \& Ika Nurul Qamari. 2011. "Eksplorasi Urgensi Pembelajaran Kewirausahaan di Perguruan Tinggi" dalam Seminar Internasional dan Call for Papers "Towards Excellent Small Business" Yogyakarta.

Zimmerer, Thomas W.,1996. Entrepreneurship The New Venture Formation. Prentice-Hall International, Inc.

Zubaedi, "Urgensi Pendidikan Kewirausahaan di Kalangan Mahasiswa PTKI" dalam Jurnal MADANIA Vol. 19, No. 2, Desember 2015. 